\title{
1 Increased Accumulation of Sulfur in Lake Sediments of the High Arctic
}

3 Paul E. Drevnick ${ }^{1,2, *}$, Derek C.G. Muir ${ }^{3}$, Carl H. Lamborg ${ }^{2}$, Martin J. Horgan ${ }^{4}$, Donald E.

4 Canfield $^{5}$, John F. Boyle ${ }^{6}$, and Neil L. Rose ${ }^{7}$

6 1. INRS-ETE, Université du Québec, 490 de la Couronne, Québec, QC G1K 9A9, Canada

8 2. Department of Marine Chemistry and Geochemistry, Woods Hole Oceanographic Institution, 9 Woods Hole, MA 02543, USA

11 3. Aquatic Ecosystem Protection Research Division, Environment Canada, 867 Lakeshore Road, 12 Burlington, Ontario L7R 4A6, Canada

4. 230 Northridge Drive, Oxford, OH 45056, USA

5. Nordic Center for Earth Evolution, Institute of Biology, University of Southern Denmark,

17 Campusvej 55, 5230 Odense M, Denmark

7. Environmental Change Research Centre, University College London, Gower Street,

22 London WC1E 6BT, UK

23

$24 \quad{ }^{*}$ Corresponding author: paul.drevnick@ete.inrs.ca; Tel. +1 418654 2519; Fax +1 4186542600 


\section{Abstract}

27 We report a synchronous increase in accumulation of reduced inorganic sulfur since c. 1980 in

28 sediment cores from eight of nine lakes studied in the Canadian Arctic and Svalbard (Norway).

29 Sediment incubations and detailed analyses of sediment profiles from two of the lakes indicate

30 that increases in sulfur accumulation may be due ultimately to a changing climate. Warming-

31 induced lengthening of the ice-free season is resulting in well-documented increases in algal

32 production and sedimentation of the resulting detrital matter. Algal detritus is a rich source of

33 labile carbon, which in these sediments stimulates dissimilatory sulfate reduction. The sulfide

34 produced is stored in sediment (as acid volatile sulfide), converted to other forms of sulfur, or

35 reoxidized to sulfate and lost to the water column. An acceleration of the sulfur cycle in Arctic

36 lakes could have profound effects on important biogeochemical processes, such as carbon burial

37 and mercury methylation. 


\section{Introduction}

39 Unprecedented warming of the Arctic is resulting in a cascade of events to push lake

40 biogeochemistry beyond its Holocene limits (1). Surface air temperatures across the Arctic

41 increased, on average, by $1.5^{\circ} \mathrm{C}$ during $c .1840-1950$, decreased slightly during c. 1950-1970,

42 and since then are increasing again, but at an accelerated rate (2, 3). From c. 1980 to the present,

43 weather stations in the Canadian Arctic archipelago and Svalbard (Norway), for example, have

44 commonly recorded upwards of $2^{\circ} \mathrm{C}$ increases in annual mean temperature $(4,5)$. The effect on

45 lake physics thus far has been to delay the formation of ice cover and to accelerate its breakup

46 (6). Quantitative records are rare, but a recent analysis of satellite images of "perennially ice-

47 capped lakes" on northern Ellesmere Island, for example, revealed that the lakes now lose a

48 substantial portion (sometimes 100\%) of ice cover during summer (7). Ice cover limits the

49 sunlight available to photosynthetic autotrophs underneath in the unfrozen water, and

50 lengthening of the ice-free season has, in effect, resulted in a longer growing season (8). Algae

51 have responded with dramatic increases in abundance and diversity (9), which, in turn, is

52 resulting in a greater flux of algal detritus to sediments. The latter is evidenced by pigment

53 records $(10,11)$, Rock Eval pyrolysis of bulk organic matter (12), and up-core increases in both

54 the accumulation of organic carbon (beyond what is expected from progressive diagenetic

55 consumption of a constant supply of organic carbon) and the ratio of ${ }^{13} \mathrm{C}$ to ${ }^{12} \mathrm{C}$ (13).

$56 \quad$ Our objective was to determine if this cascade extends to sedimentary sulfur cycling.

57 Sulfur is a major nutrient for all organisms and also plays an important role in the cycling of

58 other nutrients, trace metals, and radioisotopes, largely via dissimilatory sulfate reduction and the

59 sulfide that is produced (14). Sediments of ultraoligotrophic Arctic lakes have been compared

60 (15) to deep-sea sediments, where low rates of organic carbon flux limit sulfate reduction (16). 
61 It is an imperfect comparison, however, because sulfate reduction in freshwater systems is also

62 generally limited by low sulfate concentrations. Still, in sediments of Toolik Lake ( $68^{\circ} \mathrm{N} ; 15$ )

63 and Lake DV-09 $\left(75^{\circ} \mathrm{N}\right.$; 17) sulfide formation was thought to be at least co-limited by low

64 organic carbon content. As aptly pointed out by Chételat and Amyot (18), though, drastic effects

65 can occur with even slight increases in algal production in these resource-poor lakes. Increases

66 in the sedimentation of algal detritus rich in organic carbon may act, as is the case for sediments

67 in deep basins of the Arctic Ocean (19), to stimulate sulfate reduction. We tested this hypothesis

68 with sediment archives, incubation experiments, and newly-collected sediment cores processed

69 to preserve sulfur redox chemistry.

71 Experimental Section

72 Archived sediment cores from five lakes in the Canadian Arctic archipelago (20) and four lakes

73 in Svalbard (21) were analyzed for total reduced inorganic sulfur. Information about the lakes is

74 given in Table 1. Details of the collection, processing, and dating of cores can be found in the

75 supporting information. Sulfur analysis followed the chromium reduction method of Canfield et

76 al. (22). We selected this method because although the handling of the archived cores very likely

77 resulted in oxidation of some forms of reduced inorganic sulfur (e.g., FeS), the oxidation

78 products are still obtainable by chromium reduction. One out of every ten samples was analyzed

79 in duplicate, and the mean percent relative standard deviation (\%RSD) of duplicates was 8.6\%.

80 Concentrations were multiplied by sedimentation rates to calculate accumulation (or flux) rates

81 of total reduced inorganic sulfur.

82

Inferential statistics were used to relate accumulation rates of total reduced inorganic

83 sulfur to variables that may explain trends both within and among cores. Variables included 
84 other elements analyzed in the cores (Canada: $\mathrm{Al}, \mathrm{Zn}$, reactive $\mathrm{Fe}$, reactive $\mathrm{Mn}, \mathrm{Pb}, \mathrm{Hg}$, organic

85 C, organic N; Svalbard: Si, Ti, Ca, K, Fe, Mn, Cu, Pb, Zn, loss-on-ignition (LOI) as a proxy for

86 organic matter) and records of sulfate deposition and temperature. Elemental data are from Muir

87 et al. (20) and Boyle et al. (23). Sulfate deposition records are from ice cores (24, 25).

88 Temperature records (mean surface air temperature during June, July, and August) are from

89 Overpeck et al. (2) and were extended to the year 2000 with data from Environment Canada (4)

90 and the Norwegian Meteorological Institute (5). Within lakes, accumulation of total reduced

91 inorganic sulfur was related to each variable with simple linear regression. Among lakes,

92 relationships of possible predictors and accumulation of total reduced inorganic sulfur were

93 evaluated with a random-effects analysis-of-variance (ANOVA) approach.

94 Two lakes in the Canadian Arctic archipelago, Amituk Lake and Char Lake, were cored

95 again to better elucidate the factors controlling the sedimentary accumulation of inorganic sulfur.

96 These lakes were chosen because they are relatively easy to access from the Polar Continental

97 Shelf Program base and, for High Arctic lakes, they are well studied. Importantly, both lakes

98 have recently documented climate-induced increases in algal production $(17,26,27)$. Details of

99 core collection and processing, which was performed to minimize exposure to air and thus

100 preserve sulfur redox chemistry, can be found in the supporting information. For each lake, one

101 core was used for incubation experiments and two cores were used for analysis of sulfur forms

102 and their isotopic compositions.

103 Incubation experiments with the sediment slurries from Amituk Lake and Char Lake

104 were conducted to determine the effects of sulfate and labile carbon supplies on sulfide

105 formation. The experiment consisted of nine treatments (each consisting of three replicates): (1)

106 time-zero control (frozen at beginning of incubation), (2) control, (3) $200 \mu \mathrm{M}$ molybdate 
107 (metabolic inhibitor of sulfate-reducing bacteria), (4) $200 \mu \mathrm{M}$ sulfate, (5) $200 \mu \mathrm{M}$ acetate (labile

108 carbon), (6) $200 \mu \mathrm{M}$ molybdate and $200 \mu \mathrm{M}$ sulfate, (7) $200 \mu \mathrm{M}$ molybdate and $200 \mu \mathrm{M}$ acetate,

109 (8) $200 \mu \mathrm{M}$ sulfate and $200 \mu \mathrm{M}$ acetate, and (9) $200 \mu \mathrm{M}$ molybdate, $200 \mu \mathrm{M}$ sulfate, and 200

$110 \mu \mathrm{M}$ acetate. Details of incubation set up, which was (again) performed to minimize exposure to

111 air, can be found in the supporting information. Incubations were run for $16 \mathrm{~d}$ and $18 \mathrm{~d}$ for

112 sediments from Amituk Lake and Char Lake, respectively, and then terminated by freezing at -

$11320^{\circ} \mathrm{C}$. The incubated sediment slurries were then freeze-dried, and the dried sediment was

114 analyzed for acid volatile sulfide (AVS) according to Canfield et al. (28). We were specifically

115 interested in AVS because it represents the short-term end products of sulfate reduction. By

116 excluding other forms of reduced inorganic sulfur, which can constitute a majority of the total,

117 the likelihood of observing significant effects in these brief experiments was increased. To test

118 for differences in AVS among treatments, a one-way ANOVA and Tukey-Kramer posthoc tests

119 were performed for each lake. It should be noted that the incubations were likely not anoxic, at 120 least at the beginning, but the results indicate that sulfate reduction occurred.

121 To analyze sulfur forms and their isotopic compositions in the sediment cores from

122 Amituk Lake and Char Lake, we used a sequential extraction method similar to that of Canfield

123 et al. (28). The reduced inorganic forms extracted include AVS (primarily $\mathrm{HS}^{-}$and FeS),

124 elemental sulfur $\left(\mathrm{S}^{0}\right)$, and pyrite (as $\mathrm{Cr}$-reducible $\mathrm{S}$; CRS). The organic forms extracted include

125 hydrolyzable S (HyS) and non-CRS, both of which likely are derived from biosynthesis, but the

126 latter being more refractory than the former. One out of every ten samples was analyzed in

127 duplicate, and the mean \%RSD of duplicates was 8.8\%. Further details of the extractions can be

128 found in the supporting information. Stable sulfur isotopic compositions $\left(\delta^{34} \mathrm{~S}\right)$ were analyzed in 129 AVS, $\mathrm{S}^{0}$, and pyrite by isotope-ratio mass spectrometry (29), with a precision of at least $\pm 0.5 \%$. 
130 Concentrations of total sulfur were directly measured on a separate subsample of sediment and

131 also calculated as the sum of inorganic and organic forms. There is close agreement between the

132 measured and calculated values (see supporting information), indicating consistent recovery of

133 the different forms of sulfur. In addition to sulfur analyses, sediments were also analyzed for

134 concentrations and isotopic compositions $\left(\delta^{13} \mathrm{C}\right)$ of total organic carbon $(30)$.

135

\section{Results and Discussion}

137 Sediment archives from the Canadian Arctic archipelago and Svalbard show variable trends in

138 accumulation rates of total reduced inorganic sulfur, except at the top of the cores, corresponding

139 to the period 1980-present, where there is a synchronous increase among lakes (Figure 1). The

140 only exception to this recent increase is in Romulus Lake, which shows a decreasing trend of

141 total reduced inorganic sulfur towards the sediment surface (see supporting information, Figure

142 S1). Unlike all the other lakes in the study, Romulus Lake is meromictic and is anoxic below the

143 chemocline because of hypersaline groundwater inflow (31). Meromictic lakes are not

144 uncommon in coastal areas of the High Arctic and exhibit a dynamic sulfur cycle. At the

145 chemocline, sulfate-reducing bacteria create a sulfidic environment in which photosynthetic

146 sulfur bacteria thrive by using sulfide and other forms of reduced sulfur to fix carbon dioxide.

147 We do not know specifically the reason the surface sediment of Romulus Lake is low in total

148 reduced inorganic sulfur, but it likely relates to the biologically-active nature of sulfur in these

149 systems. In our within-lake regression modeling (see supporting information, Table S1) we

150 found no suitable predictors for total reduced inorganic sulfur in Romulus Lake. In contrast, the

151 other eight lakes in this study exhibit limnological characteristics considered more typical of the

152 Arctic - holomictic and fully oxygenated. In these lakes, sulfate reduction is limited to anoxic 
153 sediments, and the sulfide produced is either reoxidized to sulfate and lost to the water column or

154 is bound to Fe or organic matter and retained in the sediment. Accordingly, Fe and organic

155 matter (organic C, organic N, or LOI) were generally good predictors, in the within-lake

156 regression models, of total reduced inorganic sulfur. Manganese was also a good predictor in the

157 models, likely because, as for sulfur (and $\mathrm{N}$ and Fe), it is involved in the mineralization of

158 organic carbon.

159 Sulfate deposition, from ice core records, was a suitable predictor of total reduced

160 inorganic sulfur in only Char Lake, and this correlation may be a function of local disturbance

161 that coincided with peaks in the ice core record. In 1949, an air base was built near Char Lake

162 that may have caused local atmospheric pollution (32). Also, during 1969-1972 gravel was taken

163 from the lake's watershed to construct a new airstrip and this action caused a "great increase" in

164 sulfate concentration in one inflow stream (33), although the effect was temporary (26).

165 Tendammen in Svalbard may also be affected by local pollution, as this lake is located near a

166 coal-fired power plant and coal mining operations. Modern accumulation of reduced inorganic

167 sulfur in the sediments of Tendammen is an order of magnitude greater than the other Svalbard

168 lakes. In the other study lakes, however, local disturbance is slight or nonexistent, and geology

169 (sedimentary rock) and proximity to the ocean (i.e., exposure to marine aerosols) indicate that

170 natural sources of sulfate should dominate input (34), even with the human-caused circum-arctic

171 increase in sulfate deposition during the past century (24). It thus seems unlikely that the surface

172 enrichment of sulfur as observed in these sediments results from increased anthropogenic sulfur

173 sources, as is true of lakes nearer industrial centers and underlain by crystalline bedrock $(35,36)$.

174 From our statistical analyses, temperature is the most important predictor of sedimentary

175 accumulation of total reduced inorganic sulfur, and we hypothesize this relationship is not direct 
176 but rather mediated through a warming-induced biogeochemical cascade. In the within-lake

177 regression modeling, temperature was the variable most consistently associated with total

178 reduced inorganic sulfur. Further, temperature was the only significant covariate in the among-

179 lakes random-effects ANOVA modeling (Canada: $r^{2}=0.74, p=0.011$; Svalbard: $r^{2}=0.68, p=$

180 0.032). Rates of sulfate reduction do increase with temperature as an Arrhenius function (e.g.,

181 37), but there is no data to suggest that temperatures in profundal sediments of these lakes have

182 followed trends in air temperature. Instead, there is overwhelming evidence from the study lakes

183 that warming-induced lengthening of the ice-free season is resulting in increases in algal

184 production $(17,26,27,38)$. In the Svalbard lakes, there is additional evidence that the increases

185 in algal production are causing greater fluxes of organic matter to sediments (23). A link to

186 organic matter flux is also being made for the study lakes in the Canadian Arctic. For Amituk,

187 Char, and Romulus lakes, Muir et al (20) found that concentrations of organic carbon were $>10 \%$

188 higher in surface sediments compared to pre-1900 horizons. This trend is likely, in part, due to

189 the progressive diagenetic consumption of carbon following sedimentation. Outridge et al. (12),

190 however, used Rock Eval pyrolysis to show an increase in the sedimentary flux of "S2" carbon

191 in Amituk Lake. S2 is an operationally-defined term (it is measured during step 2 of the Rock

192 Eval method) and is thought to be of algal origin and resistant to diagenesis. More recently, Kirk

193 et al. (27) determined sedimentary fluxes of S2 in Amituk Lake, Char Lake, and Lake Hazen and

194 found increasing S2 in all three lakes, along with shifts in the algal community. Also, we found

195 modest up-core increases in $\delta^{13} \mathrm{C}$ in sediments from Amituk Lake (-27.2\%o to -26.5\%) and Char

196 Lake (-25.8\% to -24.7\%) (see supporting information, Figure S2) that could suggest that the

197 sedimentation of autochthonous carbon has increased recently (39). 
Urban (14) predicted that increases in autochthonous carbon flux will stimulate sulfate

199 reduction in surface sediments of ultraoligotrophic lakes with low rates of carbon sedimentation

200 and oxic hypolimnia, a fitting description of our study lakes. Sulfate-reducing bacteria derive

201 energy by transferring electrons from organic carbon compounds or $\mathrm{H}_{2}$ to sulfate (40).

202 Laboratory experiments have shown that the amendment of lake sediments with labile carbon

203 stimulates sulfate reduction (e.g., 41), which may lead to increases in storage of reduced sulfur in

204 sediments. There is a well-established relationship among algal productivity, organic carbon

205 sedimentation, and sulfur content of sediment in temperate lakes that exhibit seasonal water-

206 column anoxia (e.g., 42), but not for Arctic lakes with oxic hypolimnia. Recently, however,

207 Korhola et al. (10) and Klug et al. (43) reported concomitant increases in concentrations of

208 organic carbon and total sulfur in sediment cores from lakes in Finnish Lapland (Lake

209 Saanajärvi, 69 $\mathrm{N}$ ) and northeast Greenland (Melles Lake, $76^{\circ} \mathrm{N}$ ), respectively. In both cases,

210 the increases in sedimentary sulfur were thought to ultimately relate to climate.

211 Variation among lakes in pre-1980 accumulation rates of total reduced inorganic sulfur

212 may reflect the non-conservative nature of this element. The records from Amituk and Daltjørna

213 seem to follow trends in air temperature since the $19^{\text {th }}$ century. Char and Tendammen have large

214 peaks that could be due to local pollution. BI-02 and Yterjørna have no discernable trends. For

215 all of these lakes, however, subsurface peaks could be associated with redox gradients. Sulfur,

216 depending upon speciation, is subject to steep diffusion gradients and biological and chemical

217 redox reactions. Consequently, sulfur profiles in sediments can reflect both historical records

218 and contemporary processes. The latter can prevent interpretation of the former (36), which may

219 be the case for the pre-1980 sediments in our study lakes. The recent (post-1980) record of

220 increased accumulation rates may be evident because, as we hypothesize, it is process driven. 
Results from our incubation experiments provide clear evidence that increased supply of

222 labile carbon to Arctic lake sediments can result in increased storage of reduced sulfur (Figure

223 2). There were statistically significant differences in AVS among treatments in the incubations

224 from both Amituk Lake $\left(F_{7,14}=26.4, p<0.001\right)$ and Char Lake $\left(F_{7,16}=75.2, p<0.001\right)$. The

225 control treatments had AVS concentrations greater than initial test conditions (time-zero).

226 Conversely, all treatments involving molybdate, a metabolic inhibitor of sulfate-reducing

227 bacteria, had AVS concentrations equivalent to that of time-zero. Collectively, the results from

228 the control and molybdate treatments indicate that AVS formation is a normal process in these

229 sediments and is due to the activities of sulfate-reducing bacteria. The sulfate treatments and the

230 acetate (labile carbon) treatments had AVS concentrations greater than controls, although this

231 was only significant in the sediment from Char Lake. (A missing replicate in the control for

232 Amituk Lake caused the control to not be statistically different from several of the other

233 treatments.) Sulfate and acetate in combination resulted in even greater AVS concentrations in

234 Amituk Lake. We do not completely understand the responses to sulfate, acetate, and the two in

235 combination (i.e., how is it that sulfate alone and acetate alone caused the same relative increase

236 in AVS?). However, it is clear that both sulfate (electron acceptor) and acetate (electron donor)

237 limit sulfate reduction in the sediments of these lakes. Logic dictates, though, that if sulfate

238 concentrations in the lakes are not changing (26) but organic carbon flux to sediments is

239 increasing, it is more likely that organic carbon is driving the increases in accumulation rates of

240 total reduced inorganic sulfur observed in the sediment archives.

241 In the cores from Amituk Lake and Char Lake that were processed to preserve redox

242 chemistry, examination of the sulfur forms that comprise total reduced inorganic sulfur (AVS,

$243 \mathrm{~S}^{0}$, pyrite) indicates that AVS is likely oxidized to $\mathrm{S}^{0}$, which is then stored in sediment (Figure 
244 3). Concentrations of AVS are low at the sediment surface $(0-2 \mathrm{~cm})$, but increase with depth.

245 These AVS profiles are typical for lakes in which, at least seasonally, oxygen penetrates into

246 surficial sediments (44). Oxygen both inhibits sulfate reduction and oxidizes reduced sulfur.

247 These cores were collected in the winter season through thick ice cover - a time when, because

248 of limited algal production and sedimentation of organic matter, there is little oxygen demand in

249 the sediments and thus oxygen penetrates relatively deeply. Gobeil et al. (19) described that

250 during the open water season, however, greater algal production results in a pulse of organic

251 matter that consumes oxygen in the sediments. The oxic-anoxic boundary moves near the

252 sediment surface, below which sulfate reduction produces AVS. It is this seasonal pattern that

253 can explain the spike in concentration at the top of the $S^{0}$ profiles. There is likely an increase in

254 AVS formation during the open water season, but it is oxidized to $S^{0}$ during winter. This

255 explanation is supported by a simple mass balance, as the decrease in AVS concentration is

256 roughly equal to the increase in $S^{0}$ concentration. It is also supported by the nearly identical $\delta^{34} S$

257 values of AVS and $\mathrm{S}^{0}$, thus indicating a common source (i.e., sulfate reduction) (45). In contrast,

258 pyrite is considerably enriched in ${ }^{34} \mathrm{~S}$ compared to AVS and $\mathrm{S}^{0}$. Sedimentary pyrite formation is

259 traditionally thought to occur from the reaction of iron monosulfide (a major component of AVS)

260 and $\mathrm{S}^{0}$ (46), and results in negligible sulfur isotope fractionation (47). The pyrite in these

261 sediments, therefore, may not be formed in situ (48) but instead derive from a different source,

262 such as from weathering of sedimentary rocks in the lakes' watersheds. Values of $\delta^{34} \mathrm{~S}$ in

263 sulfides, including pyrite, from rocks on Cornwallis Island and nearby islands (typically $+10 \%$

264 (49), but reported as low as -9\% (50)) overlap with the values we find for pyrite in sediment.

265 The delivery of substances from watershed to lake has generally not yet been significantly

266 altered by climate change in the High Arctic $(1,20,26)$, and fittingly, the concentration profiles 
267 for pyrite are relatively stable, except at the bottom of the profiles from Char Lake. The

268 concentrations profiles for AVS and $S^{0}$, as well as the $\delta^{34} S$ values of all three sulfur forms are

269 similarly affected at this depth, and we think the change is due to a marine origin of the sediment

270 below 8-cm depth (Char Lake was created with post-glacial rebound approximately 6000 years

271 ago (33) and did not clear of seawater for some time (51, see figure 3 therein)).

272 An alternate hypothesis to explain the presence of $S^{0}$ in the sediment cores is that it is an

273 artifact of sample processing. Acid volatile sulfide is oxygen sensitive and, even with our

274 attempts to preserve redox chemistry (sampling ports, zinc acetate), it could have been oxidized

275 to $\mathrm{S}^{0}$ upon freeze-drying or treatment with $\mathrm{HCl}$. We cannot reject this hypothesis, but regardless,

276 it does not change our finding that the accumulation of reduced inorganic sulfur is increasing in

277 sediments of High Arctic lakes, possibly due to an increasing sedimentary flux of organic carbon

278 that is stimulating sulfate reduction. The sulfide produced is being stored as AVS and/or S .

279 Similar to the trends in total reduced inorganic sulfur, the profiles of organic sulfur show

280 an increase at the top of the cores (see supporting information, Figure S3). In both Amituk Lake

281 and Char Lake, HyS and nonCRS (forms of organic sulfur; defined in experimental section)

282 similarly show subtle increases up core and then a big jump in concentration at the sediment

283 surface $(0-2 \mathrm{~cm})$. With HyS and nonCRS added together to calculate total organic sulfur, the

284 atomic $\mathrm{C}_{\mathrm{org}} / \mathrm{S}_{\text {org }}$ ratios are relatively constant throughout the profiles for each lake and average

285193 for Amituk Lake and 103 for Char Lake. These high $\mathrm{C}_{\text {org }} / \mathrm{S}_{\text {org }}$ ratios strongly suggest that the

286 source of organic sulfur is sedimenting algae, which have $C_{\text {org }} / S_{\text {org }}$ ratios $>84$ (52), and not from

287 the diagenetic addition of reduced sulfur to organic matter. The profiles of HyS and nonCRS

288 thus reflect the loss of sulfur from the decomposition of algae. 
There is little other data on sedimentary sulfur in Arctic lakes to which we can compare

290 our results. Studies have documented sulfur profiles that increase towards the surface (10), have 291 a distinct subsurface peak associated with a redox gradient $(17,53)$, or decrease towards the 292 surface (15). Bindler et al. (54) suggested that a decrease in sulfur concentration towards the 293 surface, due to sulfide oxidation, is the steady state for lakes in the Swedish Arctic. Our results 294 indicate, however, that there is either a different steady state in lakes of the High Arctic or 295 climate warming is pushing these systems out of steady state. Perhaps, as suggested by Mueller 296 et al. (7), warming crossed a critical threshold in the 1980s and we are now witnessing a 297 “cascading regime shift”. A 250,000-year sediment record from Lake El’gygytgyn (67 $\mathrm{N})$ in 298 Siberia provides several examples of shifts in sulfur cycling in response to changes in climate 299 (55). The key to increased sulfur accumulation in the sediments of Lake El'gygytgyn is the 300 development of a stratified water column and, subsequently, the depletion of oxygen in the 301 bottom water. Our study lakes remain holomictic and fully oxygenated, but results from lakes 302 further south that receive intensive monitoring efforts (Lake Saanajärvi, Toolik Lake) indicate 303 that warmer air temperatures and extended ice-free periods will cause thermal stratification and 304 in some years oxygen-depleted bottom waters (56). Studies of Meretta Lake, located near Char 305 Lake on Cornwallis Island, but which has experienced eutrophication due to sewage inputs, 306 indicate that High Arctic lakes are indeed prone to oxygen depletion. In the early 1970s, 307 Schindler et al. (57) documented increased primary production in Meretta Lake, which led to 308 near anoxic conditions in bottom waters and a perturbation of sulfur cycling. Thirty percent of 309 sulfate in lake water was lost over winter. Sulfide was not measured in water or sediments, but 310 the missing sulfate was likely reduced and stored in sediment. 
In summary, the accumulation of sulfur appears to be increasing in sediments of Arctic

312 lakes, and we argue that the cause is a climate-induced biogeochemical cascade. It is unknown if

313 the cascade extends beyond sulfur, but sulfur does play an important role in the cycling of other

314 elements. For example, sulfate reduction mineralizes organic carbon (to $\mathrm{CO}_{2}$ that then may be

315 lost to the atmosphere) and thus works against the burial of carbon in sediments, which is an

316 important sink in the global carbon budget (58). As a side, increased carbon flux may stimulate

317 other anaerobic metabolisms, such as methanogenesis, which produces $\mathrm{CO}_{2}$ and methane, both

318 greenhouse gases, and thus would constitute a positive feedback to climate warming. Sulfate

319 reduction is also the process believed to be primarily responsible for the transformation of

320 inorganic mercury to methylmercury (59; but see 60), which biomagnifies in food webs and

321 results in high concentrations of this toxic metal in fish (61-63). A ramping up of the sulfur cycle

322 in Arctic lakes could have local to global effects on the biogeochemistry of these elements and

323 others. Further study of the flux of carbon (quality, quantity) to Arctic lake sediments and

324 effects on sulfur cycling and beyond is warranted.

325

326 Acknowledgements

327 Funding was provided by the WHOI Ocean and Climate Change Institute, the USGS WHOI

328 Postdoctoral Scholar Program, Environment Canada, the Danmarks Grundforskningsfond, and

329 the Norges forskningsråd (grant number 107745/730). Logistical support was provided by the

330 Polar Continental Shelf Program (Natural Resources Canada). Many individuals who

331 contributed to the research are acknowledged in the supporting information.

332

\section{Supporting Information Available}


334 Methods, acknowledgements, one table, three figures, and all original data.

\section{References}

337 (1) Michelutti, N.; Wolfe, A. P.; Briner, J. P.; Miller, G. H. Climatically controlled chemical 338 and biological development in Arctic lakes. J. Geophys. Res. 2007, 112, G03002, DOI

(2) Overpeck, J.; Hughen, K.; Hardy, D.; Bradley, R.; Case, R.; Douglas, M.; Finney, B.; 10.1029/2006JG000396.

Gajewski, K.; Jacoby, G.; Jennings, A.; Lamoureux, S.; Lasca, A.; MacDonald, G.; Moore, J.; Retelle, M.; Smith, S.; Wolfe, A.; Zielinski, G. Arctic environmental change of the last four centuries. Science 1997, 278, 1251-1256.

(3) Chylek, P.; Folland, C. K.; Lesins, G.; Dubey, M. K.; Wang, M. Arctic air temperature change amplification and the Atlantic Multidecadal Oscillation. Geophys. Res. Lett. 2009, 36, L14801, DOI 10.1029/2009GL038777.

(4) Environment Canada. 2010. http://www.climate.weatheroffice.gc.ca/Welcome_e.html.

(5) Norwegian Meteorological Institute. 2010. http://met.no/English/.

(6) Walsh, J. E.; Anisimov, O.; Hagen, J. O.; Jakobsson, T.; Oerelemans, J.; Prowse, T. D.; Romanovsky, V.; Savelieva, N.; Serreze, M.; Shiklamonov, A.; Shiklamonov, I.; Soloman, S. Crysophere and Hydrology. In Arctic Climate Impact Assessment; Cambridge University Press: Cambridge, U.K., 2005.

(7) Mueller, D. R.; Van Hove, P.; Antoniades, D.; Jeffries, M. O.; Vincent, W. F. High Arctic lakes as sentinel ecosystems: cascading regime shifts in climate, ice cover, and mixing. Limnol. Oceanogr. 2009, 54, 2371-2385.

(8) Smol, J. P.; Douglas, M. S. V. From controversy to consensus: making the case for recent 
climatic change in the Arctic using lake sediments. Front. Ecol. Environ. 2007, 5, 466-474.

358

359

360

361

362

363

364

365

366

367

368

369

370

371

372

373

374

375

376

377

378

379

(9) Smol, J. P.; Wolfe, A. P.; Birks, H. J. B.; Douglas, M. S. V.; Jones, V. J.; Korhola, A.; Pienitz, R.; Rühland, K.; Sorvari, S.; Antoniades, D.; Brooks, S. J.; Fallu, M. -A.; Hughes, M.; Keatley, B. E.; Laing, T. E.; Michelutti, N.; Nazarova, L.; Nyman, M.; Paterson, A. M.; Perren, B.; Quinlan, R.; Rautio, M.; Saulnier-Talbot, É.; Siitonen, S.; Solovieva, N.; Weckström, J. Climate-driven regime shifts in the biological communities of arctic lakes. Proc. Nat. Acad. Sci. USA 2005, 102, 4397-4402.

(10) Korhola, A.; Sorvari, S.; Rautio, M.; Appleby, P. G.; Dearing, J. A.; Hu, Y.; Rose, N.; Lami, A.; Cameron, N. G. A multi-proxy analysis of climate impacts on the recent development of subarctic Lake Saanajärvi in Finnish Lapland. J. Paleolimnol. 2002, 28, 59-77.

(11) Michelutti, N.; Wolfe, A. P; Vinebrooke, R. D.; Rivard, B.; Briner, J. P. Recent primary production increases in arctic lakes. Geophys. Res. Lett. 2005, 32, L19715, DOI 10.1029/2005GL023693.

(12) Outridge, P. M.; Sanei, H.; Stern, G. A.; Hamilton, P. B.; Goodarzi, F. Evidence for control of mercury accumulation rates in Canadian High Arctic lake sediments by variations of aquatic primary productivity. Environ. Sci. Technol. 2007, 41, 5259-5265.

(13) Wolfe, A. P.; Cooke, C. A.; Hobbs, W. O. Are current rates of atmospheric nitrogen deposition influencing lakes in the eastern Canadian Arctic? Arct. Antarct. Alp. Res. 2006, 38, 465-476.

(14) Urban, N. R. Retention of sulfur in lake sediments. In Environmental Chemistry of Lakes and Reservoirs; Baker, L. A., Ed.; American Chemical Society: Washington, DC 1994.

(15) Cornwell, J. C.; Kipphut, G. W. Biogeochemistry of manganese- and iron-rich sediments in Toolik Lake, Alaska. Hydrobiologia 1992, 240, 45-59. 
(16) Canfield, D. E. Sulfate reduction in deep-sea sediments. Am. J. Sci. 1991, 291, 177-188.

(17) Outridge, P. M.; Stern, G. A.; Hamilton, P. B.; Percival, J. B.; McNeely, R.; Lockhart, W. L. Trace metal profiles in the varved sediment record of an Arctic lake. Geochim. Cosmochim.

(18) Chételat, J.; Amyot, M. Elevated methylmercury in High Arctic Daphnia and the role of productivity in controlling their distribution. Global Change Biol. 2009, 15, 706-718.

(19) Gobeil, C.; Sundby, B.; Macdonald, R. W.; Smith, J. N. Recent change in organic carbon

(20) Muir, D. C. G.; Wang, X.; Yang, F.; Nguyen, N.; Jackson, T. A.; Evans, M. S.; Douglas, M.; Köck, G.; Lamoureux, S.; Pienitz, R.; Smol, J. P; Vincent, W. F.; Dastoor, A. Spatial trends and historical deposition of mercury in eastern and northern Canada inferred from lake sediment cores. Environ. Sci. Technol. 2009, 43, 4802-4809.

(21) Birks, H. J. B.; Monteith, D. T.; Rose, N. L.; Jones, V. J.; Peglar, S. M. Recent environmental change and atmospheric contamination on Svalbard as recorded in lake sediments - modern limnology, vegetation, and pollen deposition. J. Paleolimnol. 2004, 31, $411-431$

(22) Canfield, D. E.; Raiswell, R.; Westrich, J. T.; Reaves, C. M.; Berner, R. A. The use of chromium reduction in the analysis of reduced inorganic sulfur in sediments and shales. Chem. Geol. 1986, 54, 149-155.

(23) Boyle, J. F.; Rose, N. L.; Appleby, P. G.; Birks, H. J. B. Recent environmental change and human impact on Svalbard: the lake-sediment geochemical record. J. Paleolimnol. 2004, 31, 515-530. 
403 (24) Goto-Azuma, K.; Koerner, R. M. Ice core studies of anthropogenic sulfate and nitrate trends

404 in the Arctic. J. Geophys. Res. 2001, 106 (D5), 4959-4969.

405 (25) Kekonen, T.; Moore, J.; Perämäki, P.; Mulvaney, R.; Isaksson, E.; Pohjola, V.; van de Wal , 406 R. S. W. The 800 year long ion record from the Lomonosovfonna (Svalbard) ice core. J.

407 Geophys. Res. 2005, 110, D07304, DOI 10.1029/2004JD005223.

408 (26) Michelutti, N.; Douglas, M. S. V.; Smol, J. P. Diatom response to recent climatic change in 409 a high arctic lake (Char Lake, Cornwallis Island, Nunavut). Global Planet. Change 2003, $410 \quad 38,257-271$.

411 (27) Kirk, J. L.; Muir, D. C. G.; Wang, X.; Evans, M. S.; Jackson, T. A.; Kling, H.; Douglas, M.

412 S. V.; Pienitz, R.; Smol, J. P.; Yang, F. Climate change and mercury accumulation rates in 413 Canadian high and sub Arctic lake sediments. Submitted to Environ. Sci. Technol.

414 (28) Canfield, D. E.; Boudreau, B. P.; Mucci, A.; Gundersen, J. K. The early diagenetic 415 formation of organic sulfur in the sediments of Mangrove Lake, Bermuda. Geochim. $416 \quad$ Cosmochim. Acta 1998, 62, 767-781.

417 (29) Croisetière, L.; Hare, L.; Tessier, A.; Cabana G. Stable sulphur isotopes can distinguish 418 trophic dependence on sediments and plankton in boreal lakes. Freshwater Biol. 2009, 54, $419 \quad$ 1006-1015.

420 (30) Cloern, J. E.; Canuel, E. A.; Harris, D. Stable carbon and nitrogen isotope composition of 421 aquatic and terrestrial plants of the San Francisco Bay Estuarine System. Limnol. Oceanogr. $422 \quad$ 2002, 47, 713-729.

423 (31) Van Hove, P.; Belzile, P.; Gibson, J. A. E.; Vincent, W. F. Coupled landscape-lake 424 evolution in High Arctic Canada. Can. J. Earth Sci. 2006, 43, 533-546.

425 (32) Stock, N. L.; Furdui, V. I.; Muir, D. C. G.; Mabury, S. A. Perfluoroalkyl contaminants in the 
Canadian Arctic: evidence of atmospheric transport and local contamination. Environ. Sci. Technol. 2007, 41, 3529-3536.

(33) Schindler, D. W.; Welch, H. E.; Kalff, J.; Brunskill, G. J.; Kritsch, N. Physical and chemical 429 limnology of Char Lake, Cornwallis Island (75 N Lat.). J. Fish. Res. Board Can. 1974, 31, 585-607.

(34) Semkin, R. G.; Mierle, G.; Neureuther, R. J. Hydrochemistry and mercury cycling in a High Arctic watershed. Sci. Total Environ. 2005, 342, 199-221.

(35) Matisoff, G.; Holdren, Jr., G. R. A model for sulfur accumulation in soft water lake

(36) Mayer, B.; Alpay, S.; Gould, W. D.; Lortie, L.; Rosa, F. The onset of anthropogenic activity recorded in lake sediments in the vicinity of the Horne Smelter in Quebec, Canada: sulfur isotope evidence. Appl. Geochem. 2007, 22, 397-414.

(37) Knoblauch, C.; Jørgensen, B. B. Effect of temperature on sulphate reduction, growth rate and growth yield in five psychrophilic sulphate-reducing bacteria from Arctic sediments. Environ. Microbiol. 1999, 1, 457-467.

(38) Jones, V. J.; Birks, H. J. B. Lake-sediment records of recent environmental change on Svalbard: results of diatom analysis. J. Paleolimnol. 2004, 31, 445-466.

(39) Blake, Jr., W. Ratios of stable carbon isotopes in some High Arctic plants and lake sediments. J. Paleolimnol. 1991, 6, 157-166.

(40) Megonigal, P.; Hines, M. E.; Visscher, P. T. Anaerobic metabolism: linkages to trace gases and aerobic processes. In Biogeochemistry; Treatise on Geochemistry, Vol. 8; Lollar, B. S., Holland, H. D., Turekian, K. K., Eds.; Elsevier: Oxford, U.K., 2004.

(41) Smith, R. L.; Klug, M. J. Electron donors utilized by sulfate-reducing bacteria in eutrophic 
lake sediments. Appl. Environ. Microbiol. 1981, 42, 116-121.

450 (42) Gorham, E.; Lund, J. W. G.; Sanger, J. E.; Dean, Jr. W. E. Some relationships between algal standing crop, water chemistry, and sediment chemistry in the English Lake. Limnol. Oceanogr. 1974, 19, 601-617.

(43) Klug, M.; Bennike, O.; Wagner, B. Repeated short-term bioproductivity changes in a coastal lake on Store Koldewey, northeast Greenland: an indicator of varying sea-ice coverage? Holocene 2009, 19, 653-663.

(44) Holmer, M.; Storkholm, P. Sulphate reduction and sulphur cycling in lake sediments: a review. Freshwater Biol. 2001, 46, 431-451.

(45) Nriagu, J. O.; Soon, Y. K. Distribution and isotopic composition of sulfur in lake sediments of northern Ontario. Geochim. Cosmochim. Acta 1985, 49, 823-834.

(46) Berner, R. A. Sedimentary pyrite formation. Am. J. Sci. 1970, 268, 1-23.

(47) Canfield, D. E. Biogeochemistry of sulfur isotopes. Rev. Mineral. Geochem. 2001, 43, 607636.

(48) Tomkins, J. D.; Lamoureux, S. F.; Antoniades, D.; Vincent, W. F. Sedimentology of perennial ice-covered, meromictic Lake A, Ellesmere Island, at the northern extreme of Canada. Can. J. Earth Sci. 2009, 46, 83-100.

(49) Dewing, K.; Sharp, R. J.; Turner, E. Synopsis of the Polaris Zn-Pb District, Canadian Arctic islands, Nunavut, In Mineral Deposits of Canada; Special Publication No. 5; Geological Association of Canada, Mineral Deposits Division: St. John’s, NL, Canada, 2007.

(50) Rose, S. R. A. Sedimentology and diagenesis of the Lower Blue Fiord Formation carbonates in a prospective Mississippi Valley-Type (Pb-Zn) setting, Bathhurst Island, NWT. M.Sc. Thesis, University of Calgary, Calgary, AB, Canada, 1999. 
472 (51) de March, L. Permanent sedimentation of nitrogen, phosphorus, and organic carbon in a 473 High Arctic lake. J. Fish. Res. Board Can. 1978, 35, 1089-1094.

474 (52) Urban, N. R.; Ernst, K.; Bernasconi, S. Addition of sulfur to organic matter during early 475 diagenesis of lake sediments. Geochim. Cosmochim. Acta 1999, 63, 837-853.

476 (53) Guilizzoni, P.; Marchetto, A.; Lami, A.; Brauer, A.; Vigliotti, L.; Musazzi, S.; Langon, L.;

477 Manca, M.; Lucchini, F.; Calanchi, N.; Dinelli, E.; Mordenti, A. Records of environmental 478 and climatic changes during the late Holocene from Svalbard: palaeolimnology of $479 \quad$ Kongressvatnet. J. Paleolimnol. 2006, 36, 325-351.

480 (54) Bindler, R.; Wik-Persson, M.; Renberg, I. Landscape-scale patterns of sediment sulfur 481

(55) Melles, M.; Brigham-Grette, J.; Glushkova, O. Yu.; Minyuk, P. S.; Nowaczyk, N. R.; Hubberten, H. -W. Sedimentary geochemistry of core PG1351 from Lake El'gygytgyn - a sensitive record of climate variability in the East Siberian Arctic during the past three glacial-interglacial cycles. J. Paleolimnol. 2007, 37, 89-104.

(56) Prowse, T. D.; Wrona, F. J.; Reist, J. D.; Gibson, J. J.; Hobbie, J. E.; Lucie M.J. Lévesque, L. M. J.; Vincent, W. F. Climate change effects on hydroecology of Arctic freshwater ecosystems. Ambio 2006, 35, 347-358.

(57) Schindler, D. W.; Kalff, J.; Welch, H. E.; Brunskill, G. J.; Kling, G. J.; Kritsch, N. Eutrophication in the High Arctic - Meretta Lake, Cornwallis Island ( $75^{\circ} \mathrm{N}$ Lat.). J. Fish. Res. Board Can. 1974, 31, 647-662.

(58) Cole, J. J.; Prairie, Y. T.; Caraco, N. F.; McDowell, W. H.; Tranvik, L. J.; Striegl, R. G.; Duarte, C. M.; Kortelainen, P.; Downing, J. A.; Middleburg, J. J.; Melack, J. Plumbing the global carbon cycle: integrating inland waters into the terrestrial carbon budget. Ecosystems 
2007, 10, 171-184.

496

497

498

499

500

501

502

503

504

505

506

508

509

510

511

512

(59) Compeau, G. C.; Bartha, R. Sulfate-reducing bacteria: principal methylators of mercury in anoxic estuarine sediment. Appl. Environ. Microbiol. 1985, 50, 498-502.

(60) Loseto, L. L.; Siciliano, S. D.; Lean, D. R. S. Methylmercury production in High Arctic wetlands. Environ. Toxicol. Chem. 2004, 23, 17-23.

(61) Rognerud, S.; Grimalt, J. O.; Rosseland, B. O.; Fernandez, P.; Hofer, R.; Lackner, R.; Lauritzen, B.; Lien, L.; Massabuau, J. C.; Ribes, A. Mercury and organochlorine contamination in brown trout (Salmo trutta) and Arctic charr (Salvelinus alpinus) from high mountain lakes in Europe and the Svalbard archipelago. Water Air Soil Pollut. Focus 2002, 2, 209-232.

(62) Muir, D.; Wang, X.; Bright, D.; Lockhart, L.; Köck, G. Spatial and temporal trends of mercury and other metals in landlocked char from lakes in the Canadian Arctic archipelago. Sci. Total Environ. 2005, 351-352, 464-478.

(63) Gantner, N.; Muir, D. C.; Power, M.; Iqaluk, D.; Reist, J. D.; Babaluk, J. A.; Meili, M; Borg, H.; Hammar, J.; Michaud, W.; Dempson, B.; Solomon, K. R. Mercury concentrations in landlocked Arctic char (Salvelinus alpinus) from the Canadian Arctic. Part II: influence of lake biotic and abiotic characteristics on geographic trends in 27 populations. Environ. Toxicol. Chem. 2010, 29, 633-643. 
513 Table 1. Information about the study lakes, including the years archived sediment cores were collected.

\begin{tabular}{|c|c|c|c|c|c|c|c|c|c|}
\hline Lake & Country, locality & Lat. N & Long. E/W & $\begin{array}{l}\text { Area } \\
\left(\mathrm{km}^{2}\right)\end{array}$ & $\begin{array}{l}\text { Max. depth } \\
\text { (m) }\end{array}$ & $\begin{array}{c}\text { Epilimnetic } \mathrm{SO}_{4} \\
(\mu \mathrm{M})\end{array}$ & $\begin{array}{l}\text { Sed. rate }{ }^{1} \\
\left(\mathrm{~g} / \mathrm{m}^{2} \cdot \mathrm{yr}\right)\end{array}$ & $\begin{array}{c}\text { Sed. org. } C^{1,2} \\
(\%)\end{array}$ & Yr. collected \\
\hline Amituk & Canada, Cornwallis Is. & $75^{\circ} 02^{\prime} 40^{\prime \prime}$ & $93^{\circ} 48^{\prime} 40^{\prime \prime} \mathrm{W}$ & 0.38 & 43 & 16.6 & 260 & 0.89 & 2003 \\
\hline Char & Canada, Cornwallis Is. & $74^{\circ} 42^{\prime} 20^{\prime \prime}$ & $94^{\circ} 53^{\prime} 50^{\prime \prime} \mathrm{W}$ & 0.53 & 28 & 132 & 240 & 1.73 & 2003 \\
\hline BI-02 & Canada, Bylot Is. & $73^{\circ} 02^{\prime} 30^{\prime \prime}$ & $80^{\circ} 05^{\prime} 45^{\prime \prime} \mathrm{W}$ & 0.033 & 3 & 4.37 & 200 & 6.04 & 2005 \\
\hline Hazen & Canada, Ellesmere Is. & $81^{\circ} 49 ' 20^{\prime \prime}$ & $70^{\circ} 37^{\prime} 50^{\prime \prime} \mathrm{W}$ & 538 & 267 & 108 & 280 & 1.67 & 2005 \\
\hline Romulus & Canada, Ellesmere Is. & $79^{\circ} 52^{\prime} 15^{\prime \prime}$ & $85^{\circ} 05^{\prime} 10^{\prime \prime} \mathrm{W}$ & 4.4 & 60 & . & 820 & 2.16 & 2000 \\
\hline Daltjørna & Norway, Svalbard & $77^{\circ} 33^{\prime} 50^{\prime \prime}$ & $14^{\circ} 13^{\prime} 55^{\prime \prime} \mathrm{E}$ & 0.054 & 11 & 16.2 & 460 & . & 1995 \\
\hline Tenndammen & Norway, Svalbard & $78^{\circ} 06^{\prime} 00^{\prime \prime}$ & $15^{\circ} 02^{\prime} 00^{\prime \prime} \mathrm{E}$ & 0.15 & 2.5 & 164 & 540 & . & 1995 \\
\hline Yterjørna & Norway, Svalbard & $78^{\circ} 13^{\prime} 52^{\prime \prime}$ & $12^{\circ} 56^{\prime} 30^{\prime \prime} \mathrm{E}$ & 0.14 & 2.6 & 36.9 & 140 & . & 1995 \\
\hline Ossian Sarsfjellet & Norway, Svalbard & $78^{\circ} 57^{\prime} 04^{\prime \prime}$ & $12^{\circ} 28^{\prime} 38^{\prime \prime} \mathrm{E}$ & 0.13 & 26 & 25.4 & 88 & . & 1995 \\
\hline
\end{tabular}

${ }^{1}$ Data for recent horizons (post-1990)

${ }^{2}$ Organic C not measured in sediments from Svalbard lakes; LOI data can be found in Boyle et al. (23). 
Figure captions

515

516 Figure 1. Accumulation rates of reduced inorganic sulfur in lake sediments from the Canadian

517 Arctic archipelago (A) and Svalbard (B). Note that the scale is different for each lake. Also

518 presented for each region are records of air temperature in summer (JJA = June, July, August)

519 and sulfate concentration in ice cores. The temperature anomaly records have sigma units, which

520 are defined in Overpeck et al. (2). Details about the sources for the temperature and sulfate

521 records can be found in the text.

522

523 Figure 2. Concentrations of acid volatile sulfide (AVS) in sediment slurries from Amituk Lake

524 (A) and Char Lake (B) after incubation with treatments of molybdate $\left(\mathrm{MoO}_{4}\right.$; metabolic inhibitor

525 of sulfate-reducing bacteria), sulfate $\left(\mathrm{SO}_{4}\right.$; electron acceptor for sulfate-reducing bacteria),

526 and/or acetate $\left(\mathrm{CH}_{3} \mathrm{COO}\right.$; electron donor for sulfate-reducing bacteria). Further details about the

527 treatments can be found in the text. Values represent the mean ( $\pm 1 \mathrm{SE}$ ) of three replicates; units

528 are in dry weight. Lowercase letters (a, b, c, d) denote statistically significant groupings as

529 determined, for each lake, by a one-way ANOVA and Tukey-Kramer posthoc tests. The $x$-axis

530 meets the $y$-axis at the initial (time zero) concentration in sediment slurries for each lake.

532 Figure 3. Sediment profiles from Amituk Lake (A) and Char Lake (B) of acid volatile sulfide

533 (AVS; circles), elemental sulfur ( $\mathrm{S}^{0}$; triangles), pyrite (squares), and the stable sulfur isotopic

534 compositions $\left(\delta^{34} \mathrm{~S}\right)$ of each of these forms of reduced inorganic sulfur. For profiles of AVS, $\mathrm{S}^{0}$,

535 and pyrite, values represent the mean ( \pm 1 SD) of two cores; units are in dry weight. For profiles

536 of $\delta^{34} \mathrm{~S}$, materials from the two cores from each lake were pooled for analysis. 


\section{Brief}

539 A recent increase in sedimentary accumulation of reduced sulfur in High Arctic lakes may be 540 due ultimately to a changing climate. 